\title{
University Social Studies Students' Knowledge of the Components of Environmental Education and Their Participation in Environmental Protection
}

\author{
Dania, P. 0. \\ Department of Social Science Education, \\ Delta State University, Abraka.
}

\begin{abstract}
This study investigated University Social Studies students' knowledge of the components of Environmental Education and their participation in environmental protection. The study outlined the knowledge components of Environmental Education to include verification ability and ability to synthesize environmental issues. A sample of five hundred (500) students was used for the study from universities where social studies education programme exists. The design used for the study was a survey design method. The research used a self-structured instrument tagged 'Knowledge Component and Participation in Environmental Protection' Questionnaire (KCPEQ). Two hypotheses were formulated to guide this study and these were analyses using Person Product Moment Correction Analysis (PPMC). It was fund out that students' verification ability of environmental problems influences their participation in environmental protection. It also revealed that students ability to synthesize environmental Education issues significantly influence their participation in environmental protection. It was on this basis that it was recommended that verification of environmental problems be made internal respect of Environmental Education curricula. Students should be made to make-on-the-spot assessment of degraded environment in their course of study. Also, information gathered from various environmental issues should avail students to participate significantly in environmental protection.
\end{abstract}

Key Words: Social Studies Students; Knowledge of environmental education components; Environmental Education; Environmental Protection.

\section{INTRODUCTION}

Nigeria is faced with myriads of environmental protections. It is unfortunate that these problems keep on increasing. These trends can only be arrested if effective counter measures are undertaken. The problems of desert encroachment, shrinking of forests, intensive erosion, flooding and the ozone layer depletion have caused untold hardship for the Nigerians in particular and the world at large. In view of this, thousands of plant and animal species are disappearing from our environments. Many people are displaced from their homes. Toxic and human measles are polluting the air, water and land, coupled with the appearance of unknown or never-experienced diseases. All these are caused by human activities which are inimical to man himself, his habitat and his future.

Tbilisi's Conference of 1978 expressed, that environmental education is an evolutionary process which centres on man and that education should be used to build sense of value in man to achieve his wellbeing and the survival of human species. The conference opined that environmental education force should reside mainly on the initiatives of learners and their commitment to action guided by both immediate and future concerns. 
To solve environmental problems, the knowledge of the problems of pollution, depletion of natural resources, soil erosion, deforestation and desertification, loss of biological and wildlife species, toxic waste management and other ecological problems inculcated into students can go a long way to enhance their awareness and effective utilization of the environment (Odumosu, 1990).

Corroborating Odumosu, Okebukola (1990), defined environmental education as including all activities that are geared towards the promotion of affective and cognitive development to enhance the understanding of the biological and physical environments. Anijah-Obi, 1993 observed that the objective of environmental education is to appropriate identification of the environment so as to know how to handle it without creating problems. He further stressed that any environmental education programme should be involved in the acquisition of knowledge that will help individuals and social groups aim understanding of the environment. He stress that it is to acquire positive value, to participate actively in solving environmental problems.

In 1998, NERDC infused topics into the curriculum of the primary and secondary educational institutions. This single action of the Nigeria Educational Research and Development Commission (NERDC) has resulted in teachers' willingness and ability to adopt environmental education materials that will encourage students to participate actively in the protection of their immediate and remote environments. Though steps have been taken to address the degrading environments in the developing world, it is sad to say that environmental situation in Nigeria still remains uncertain.

World Health Organisation (1976) stressed the appalling situation that ground in the developing nations like thick with human organic and inorganic wastes. People live under harsh conditions and health hazards causing epidemic coupled with overcrowding, forests and shrinking, desert encroaching and areas of cultivable soils are eroding fast. Man activities are depleting the ozone layers environmental change and heat wave and its resultant global warming.

\section{THEORIES OF ENVIRONMENTAL PROTECTION}

The first law of ecology is in-optimum law which posits that no specie in a given habitat encounters the optimum conditions for all its function. It therefore becomes unavoidable for man to ensure the environment is made to accommodate the specie's needs and functionality. In doing this, many species are eliminated. It is their imperative for man to device means of preserving the environment.

The second law of ecology posits that organic evolution is shower than environmental change consequent upon this man must need device a means of conserving the degrading environment. The law of environmental tolerance holds that species are confined logically and geographically against any extremes of environmental adversities so that it can survive. The implication of this laws is that there are two levels (lower and upper) of tolerance within which an organism should be kept to function maximally.

Added to the above laws, is the law of persistence which has a significant relationship with environmental conservation: That is to say that many species in the community will survive as long as their original state in their habitat is maintained and their vitality favoured. The implication of this law in ensuring environmental protection is that, man should be concerned with the state of his environment. Environment may not be able to provide adequately for his 
sustainability. Man should ensure the protection of his environment in order to survive therein.

There is a global worry and concern about environmental degradation. This problem is occasioned by human activities which result in ozone layer depletion, desertification, deforestation, erosion, over population, water, land and air pollution (Osibaiyo, 1991) and Adeniyi, 1997, cited in Ogwuabor (1991). Resulting from above, there is epidemic which poses threat to man existence. Man is being affected by his ignorance of his environment, man needs to be constantly educated about his environment since he is ignorant of his actions which are adversely affecting his environment. He needs to be acquainted with global concerns that affect man in his environment. If man is ignorant of the things that go on around him, there is band to remain stagnant and unable to contribute to environmental development. Man has to be well informed or educated about his environment to ensure is continuous development. This is why all aspects of environmental education hold significant role in environmental protection.

The pertinent question that comes to mind is, can the knowledge component of environmental education be useful in ensuring environmental protection? This study is to find out if emphasis on the knowledge components of environmental education will enhance students' participation in environmental protection more specifically, the study is to ascertain if ability of students to verify environmental problems will influence their participation in environmental protection. The study is also to investigate if students' ability to synthesize environmental issues will influence their participation in environmental protection.

This study is very finely and appropriate considering the huge fund on education by the government. The study will enhance peoples' awareness of environmental problems. The study will develop in the people the knowledge, motivation and commitment towards protecting their remote and immediate environment. Above all, this study will stimulate teachers to emphasize the knowledge components of environmental education instead of memorization and regurgitation by students the concepts of environmental education. The study serves as an important feedback on the getting the people to be involved in reducing environmental problems.

\section{RESEARCH QUESTIONS}

To guide this study, the following research questions and research hypotheses are put forward

1. What is the students' understanding of the knowledge components of environmental education and their participation in its protection?

2. Does ability to verify environmental problems affect the students' participation in the protection?

3. Is there any significant effect of students' ability to synthesize environmental education issues on their participation in environmental protection?

\section{Hypotheses}

The consequent hypotheses are therefore stated:

Ho1 There is no significant relationship between students' verification ability of environmental problems and their participation in environmental protection.

Ho2 There is no significant relationship between students' ability synthesize environmental education issues and their participation in environmental protection. 


\section{Concept of Knowledge}

\section{REVIEW OF LITERATURE}

There is no definite definition of the word 'Knowledge'. But knowledge can be defined descriptively. Bloom (1956), defined knowledge as a recall of specifics and universals recall of methods, processes and recall of patterns and structures of setting (P.14). Taba in (1962) gives four levels of knowledge as being specific facts and processes. Basic ideas, concepts and thought systems.

Explaining the above mentioned level, Taba said that the first level has to do with the facts an individual has at his disposal to describe the ideas or phenomena at a low level of abstraction. The basic idea level enables the individual to explain the relationship existing between and among principles. This helps him to verify causal relationship between ideas. The level of concept is the complex process through which an individual uses abstract ideas and multiple causation to thread events in a combined or synthetic perspectives while the thought system level enables the individuals to acquire the ability make inquiry into happenings in the one's environments.

Olarinoye (1997) opined that environmental education being an applied descriptive helps individual to combine knowledge got from the field to protect the environment. Barth (1972) said a rich environment avail children with a range of manipulative materials for them to acquire knowledge which will help them to handle the environment.

Edmond and George (1972) held that knowledge gained about the environment help an individual to contribute to the conservation of the environment. The knowledge gained include concepts acquired from related sciences and when internalized will help individual to be involved in solving environmental problems in a wholistic manner. Boughey (1975) in Okebukola (1993) lamented the exclusion of ecological consideration in the development of model cities, including some modern capital rather focus in perpetually placed in the architectural consideration.

Udo and Akpa (1997) sees environmental education as a practical process for equipping man with knowledge, skills and commitment to improve his environment and often necessary measures that will protect the ecosystem. The inclusion of environmental issues in to the Nigerian education curricula cannot be compromised in her quest to avert the disastrous effect of global warming, destruction biological diversities pollution of local and international waters and the depletion of the ozone layers. Environmental education makes an individual to be familiar with environmental problems, awake the consciousness of the individual about the safety of the environment and experiencing how environmental problems have arisen and how these can be ameliorated.

Noibi and Lawal Anijah-Ob (1993) gave a succinct outline of environmental education to include the creation of awareness that the environment all over the world is under threat of degradation and devastation. He also observed that the survival of the environment is the survival of man and the misery of the environment is the misery of man.

\section{International Cooperation and Understanding}

Environmental problems transcend national boudoirs hence should be given global treatment. Industrial emissions including carbondioxide (Co2), Methane, Nitrous Oxide (NO) chloro carbons (CFCs) causing global warning with their disastrous effect should be controlled internationally. 
Environmental education should be used as an instrument par excellence globally consciousness about the effects of these industrial processes that can cause health hazards to the global community. Environmental Education is needed to foster international cooperation and understanding in solving these global environmental problems though environmental education the transnational environmental problems will be made known to the citizens of various country to enable the countries avoid these problems (UNEP, 1987)

\section{Synthesis of Ideology and Attitude Change towards Environment}

Environmental Education makes available how ideas that will change our long held attitudes and wisdom. Our social, religious and cultural beliefs and activities as well as our life styles and consumption patterns are in conflict environmental demands. This calls for interaction of our long (old) ideas with the current state of the environment which will avail the citizen of countries to forge the idea of keeping the environment safe. (Reich and Adcock, 1976 and Dania, 2002).

\section{Education as a Strategy in Promoting Environmental Consciousness}

Though the environment is both physical and biological, the social political, economic and ethical components determine significantly man's relationship with his environment and how he uses the natural resources to meet his needs. Education being a strong instrument to ensure behavioural change, can be both formal and informal education. This education should be able to inculcate basic knowledge and skills such as verification ability and synthesis of ideas in successful environmental management practices (Okigbo, 1991).

Anijah-Obi (1993) suggested that education should be used to acquire environmental consciousness, this reduce the vague awareness of the environment by the people. This study used expose facts design using survey method to find out the relationship between nonmanipulated variables and knowledge components of environmental education and the manipulated variable (participation in environmental protection. This a non-experimental study which provides qualitative and quantitative descriptions of university social studies students' knowledge of components of environmental education and participation in environmental protection though the use of questionnaire.

\section{Research Design}

\section{METHODOLOGY}

The design for this study was the survey research design.

\section{Population of the Study}

The study covers all universities offering Environmental Education in Nigeria at under graduate level. The study population is five thousand (5000) students.

\section{Sample of the Study}

The sample of students for the study is five hundred (500) drawn purposively because of the very typical nature of the study. 
Table 3.1 Distribution Of Students' Sample

\begin{tabular}{|l|l|}
\hline UNIVERSITY & NO OF STUDENTS \\
\hline University of Calabar & 100 \\
\hline University of Uyo & 100 \\
\hline University of Benin & 100 \\
\hline Lagos State University & 100 \\
\hline University of Abuja & 100 \\
\hline Total & $\mathbf{5 0 0}$ \\
\hline
\end{tabular}

\section{Reliability of the Instrument}

The reliability of the instrument was obtained by conducting a pilot study on fifty university of Uyo. The reliability co-efficient of 0.80 using test-retest method.

\section{Data Collection}

The researcher administered the instrument personally with the help of some staff of the various institutions used for the study.

\section{Data Analysis}

The Person product moment correlation co-efficient analysis was used in comparing the mean scores of responds in respect to their participation in environmental protection.

\section{Hypotheses Testing}

\section{Hypothesis One}

Ho1 There is no significant relationship of students' verification ability of environmental problems with their participation in environmental protection.

Table 4.1: Product Moment Correlation Analysis of Verification Ability and Participation in Environmental Protection

\begin{tabular}{|l|llll|}
\hline VARIABLES & $\sum \mathrm{x}$ & $\sum \mathrm{x}^{2}$ & & \\
& $\sum \mathrm{y}$ & $\sum \mathrm{y}^{2}$ & $\sum \mathrm{xy}$ & rxy \\
\hline Verification Ability & 12833 & 346125 & 354823 & 0.493 \\
& & & & \\
Participation in & & & & \\
Environmental Protection & 13807 & 394243 & & \\
\hline
\end{tabular}

$$
P<05(N=500) \text { df } 498 \text { crt } R=0.088 \text {. }
$$

In table 4.1 , the calculated $r$-value was 0.493 compared with the critical $r$-value 0.088 at 0.05 level of significance with 498 degree of freedom. The null hypothesis was rejected since the calculated r-value was greater than the critical-r-value. This means there is significant relationship between students' verification ability of environmental problems and their participation in environmental protection.

\section{Hypothesis Two}

Ho2 There is no significant relationship between students' ability to synthesize environmental issues and their participation in environmental protection. 
Table 4.2: Product Moment Correlation Analysis of Verification Ability to Synthesize and Participation in Environmental Protection

\begin{tabular}{|l|lllr|}
\hline \multicolumn{1}{|c|}{ VARIABLES } & $\sum \mathrm{x}$ & $\sum \mathrm{x}^{2}$ & & \\
\hline Ability to synthesize & $\sum \mathrm{y}$ & $\sum \mathrm{y}^{2}$ & $\sum \mathrm{xy}$ & rxy \\
$\begin{array}{l}\text { Participation in } \\
\text { Environmental Protection }\end{array}$ & 14814 & 446679 & 409094 & 0.987 \\
& & & & \\
\hline
\end{tabular}

$P<05 \quad(\mathrm{~N}=500) \mathrm{df}=498$ crt $\mathrm{R}=0.088$.

Table 4.2 shows that the calculated $r$-value was 0.987 while the critical $r$-value was 0.088 at 0.05 significance level and at 498 degree of freedom. As the calculated r-value (0.987) was greater than the critical r-value (0.088), the null hypothesis is rejected. This means that students' ability to synthesize environmental education issues, significantly related to their participation in environmental protection.

\section{Discussion of Results}

\section{DISCUSSION}

The data summarised in table 1 confirmed significant relationship of students' ability to verify environmental problems with their participation in environmental protection. The finding supports the postulation of Olarinoye (1997) who states that students' who can appropriately measure the alkalinity and acidity of the soil in the presence of essential elements and their influence on the life of people in the environment are always cautious about its conservation. This finding is pertinent because measurement is done to verify facts about events or process. Furthermore, when events and processes are determined the probable negative effects are consciously and cautiously avoided. Berth (1972) supports in assumption on learning and knowledge acquisition states that the inherently curious and exploratory behaviour of learners drive them to be curious about their environment. These further make him to search and explain himself and his environment. Therefore, make him to master his environment and make him to be actively involved in the events of the environment positively.

In considering the ability to synthesize environmental education issues and participation in environmental protection, a significant relationship was observed. This is in agreement with the findings of Olarinoye (1997), Udo and Akpa (1997) and Barth (1972) who concluded that a rich environment offering a wide range of manipulative material, and information leads to active learning and getting them involved also in what goes on in the environment. Olarinoye also observes that environmental education is an applied field of study that equips man to make synthesis of various facts about the environment for its protection.

\section{Implications of Study Outcomes}

It was deduced that ability of students to verify environmental problems makes the students to be aware of the existence of environmental problems. The process of verification registers permanently in their consciousness, the impacts of problems in the environment have on the environment. The process of verification of environmental problems gets the students to be familiar with the problems and consequently makes them to avoid activities that will further degrade the environment.

Students' ability to synthesize environmental education issues offers the students a wide range of opportunities to learn about the environment. It is therefore deduced from every dimension will further ginger students' knowledge in their study of the environment and their consequent participation their environmental protection. 


\section{Conclusion}

\section{CONCLUSION AND RECOMMENDATIONS}

Conclusively, students who are able to verify environmental problems develop capacity to participate in environmental protection. Since they can ascertain the reality of environmental problem, they will have the knowledge of how to go on to address them.

Furthermore, the availability of a range of information on environmental education issues avails students the opportunities to familiarize them with environmental issues. The information they acquire about the environment enables them to get involved in activities that will affect the environment either positively or negatively.

\section{Recommendations}

1. The researcher recommends that verification of environmental problems should made an important aspect of environmental education curricula. Should avail the opportunity to make on-the-spot assessment of their environment in their cause of study.

2. Since environmental Education is an applied field of study, students' should be opportune to widely be involved in all aspects of the environments. This will enable them to gather information about the environment. From a wide range events they will be subjected to in their course of study.

3. Environmental Education should be made multidisciplinary. This will widen the knowledge of students about the environment and their participation in environmental protection.

4. Environmental Education should be made a core or compulsory course of study at both levels of education in the world over.

\section{References}

Adeniyi, E. O. (1999). Curriculum Issues in the teaching of biodiversity, conservation and desertification in Okebukola and Akpan (Eds) strategies for Environmental Education Series No. 3 of STAN.

Anijah-Obi, F. N. (1993). Communication process in environmental education a class module (Unpublished).

Barth, R. S. (1972). Assumption about learning and knowledge. California. Agathon Press Incorporated.

Edmund, F. and George, S. R. (1975) Introduction to Contemporary Psychology. California W. H. Freeman and Company.

Nigeria Education Research and Development Council (1998). POP. ED news. Vol 1, No.2. passim.

Odumosu, A. (1990). Introducing environmental education into secondary school through introductory technology. Environmental Education Workshop and Seminar proceedings. Vol. 1.

Ogwuazor, K. E. (1999). Strategies for teaching desertification and biodiversity conservation. In Okebukola, P. and Akpan, B. B. (Eds) Strategies for environmental education focus on desertification and Biodiversity conservation. Environmental Education series N. 3 of STAN.

Okebukola, P. A. (1995). Elements of environmental education in senior secondary schools biology seminar proceedings. Vol.1.

Okebukola, P. A. (1999). Teachers' Perception of the effectiveness of the strategies for environmental education. STAN environmental project Lagos:

Okigbo, F. N. (1991). Development of sustainable agricultural production system in Africa roles of international agricultural research centres and national agricultural research system. Ibadan: II TA.

Olarinoye, R. D. C. (1997). Curricula issues in Integrating concepts of sustainable development in education. in Udo and Akpa (1997) (Eds) environmental education for sustainable development. A focus on Nigeria. Jos FAB educational books.

Noibi, S. T. and Lawal, M. J. (1989). Reading in environmental education for tertiary institutions. Lagos: Refueld Nigeria Limited. 
Taba, H. (1962). Curriculum development. New York: Harcourt Brace and World Inc.

Reich, B. and Adcock, C. (1976). Values attitudes and behaviour changes Methuen and Co. Limited.

Udo, S. A. and Akpa G. O. (Eds) (1997). Environmental Education for sustainable development Jos: FAB education Books.

UNEP (1987). The United Nations Environmental Programme. Nairobi Kenya: 